\title{
Pursuing a Shared Future in the Face of Globalization: Four Essential Questions
}

\author{
Byron Bland $^{1} \&$ Lee Ross $^{2}$ \\ ${ }^{1}$ Fellow, King Institute, Stanford University; Senior Consultant, Stanford Center on International Conflict and \\ Negotiation, Stanford University, USA \\ ${ }^{2}$ Professor of Psychology at Stanford University and Principal Investigator at the Stanford Center on International \\ Conflict and Negotiation.
}

Correspondence: Byron Bland. E-mail: bland@ @law.stanford.edu

Received: May 19, 2018 Accepted: June 15, 2018 Online Published: June 25, 2018

doi:10.11114/ijlpa.v1i1.3383

URL: http://dx.doi.org/10.11114/ijlpa.v1i1.3383

\begin{abstract}
This paper discusses the "four-question" framework (Bland, Powell, \& Ross, Barriers to dispute resolution: reflections on peacemaking and relationships between adversaries, 2012) that we and our colleagues developed in working to promote constructive dialogue and difficult compromises on the part of groups engaged in seeming intractable conflicts in Northern Ireland and Israeli/Palestine. The key feature of this framework is the need for the vision of a bearable shared future and commitment to pursue that future. Three other features of this framework are the need to build trust that commitments will be honored, the need for parties to understand and acknowledge the losses each will bear in accepting that future, and the need for the parties to settle for less than they feel justice demands, but also address the most serious current sources of injustice. This framework, we suggest, provides a useful lens for understanding and bridging the political divides apparent today in the US and many other democratic countries facing not only the economic threats and losses that globalization has imposed on vulnerable groups, but also threats and losses relating to weakening of community life and feelings of personal dignity We also discuss the phenomenon of loss aversion (Kahneman \& Tversky, 2000) and its role in creating susceptibility to the rhetoric of hate-mongering populist leaders. We note the obvious need to provide a decent standard of living and greater security for the most vulnerable, but the further need to do so in a non-humiliating manner, and we also address the need to distinguish acceptable imperfect, difficult compromises from unacceptable ones.
\end{abstract}

Keywords: conflict resolution, globalization, polarization, loss aversion, trust.

\section{Introduction}

Our world today seems engulfed in crises-economic, environmental, and cultural, as well as political and military - that call for action. Within the United States, in the aftermath of the 2016 Presidential Election, the crisis most discussed is a political one. The country is said to be divided into two political camps and cultures. One is centered in racially diverse, largely secular and "post-industrial" cities and surrounding suburbs. The other camp, centered in small-town and rural communities, is overwhelmingly white and Christian, with inhabitants earning their living, at least historically, in manufacturing, agriculture, mining, and other resource extracting industries.

The first camp supported Hillary Clinton, in many cases despite misgivings about Clinton, because they rejected Donald Trump's populist message. Many also saw him as a dangerous demagogue ill-suited by temperament and qualifications to assume the powers and responsibilities of the Presidency, The second camp supported Trump. Some members did so enthusiastically, others because they did not hear anyone else speaking to their grievances and concerns. Post-election analyses revealed that Clinton won 87 of the country's 100 most populous counties, and scored heavily with young and minority group voters. Trump, by contrast, won 2600 of the remaining 3000 counties, and handily won the support of blue-collar and other non-college educated voters. ${ }^{i}$

Most contemporary discussions of this divide cite the challenges created by globalization. We begin this paper by briefly describing the role that globalization has played in creating political divisions, with a particular focus on "loss aversion" and other psychological barriers faced in meeting those challenges. ${ }^{\text {ii }}$ We then introduce a "four-question framework" that we developed with our colleagues at the Stanford Center on International Conflict and Negotiation 
(SCICN) as we worked with peace-seekers and community-builders in Northern Ireland, Israel-Palestine, and other areas of intergroup and intragroup conflict. We suggest that this framework, with its emphasis on the need to articulate and work toward a "bearable future" for the relevant stakeholders, offers a path forward in the face of the current intergroup and intragroup divisions within American society.

\section{Globalization, Globalism, and the Future of Work and Community Life}

As many observers have noted, contemporary forces have cleaved the US and other industrial nations into two very distinct realms. ${ }^{\text {iii }}$ Urban, cosmopolitan centers (New York, San Francisco, Paris, London, Berlin, etc.) today are thriving economically, culturally, and socially. They are destinations for global travelers, featuring first-class restaurants, elegant shopping, museums and cultural exhibitions. They are the places to be, where things are happening and where life is exciting. While immigration, the high cost of housing, and changes in the job market have created a measure of social tension and economic stress for many urbanites, life for the majority remains rich and rewarding. Most see avenues for personal fulfillment and family life, even if those rosy prospects are by no means certain.

The rest, those "left behind" in small town and rural areas, have fared less well. They have seen their industries close, their jobs leave, the shops on their Main Streets shuttered, and their community life deteriorate beyond recognition. ${ }^{\text {iv }}$ In the US, many of these communities are experiencing an opioid addiction epidemic that dwarfs the death rates caused by previous heroin and crack cocaine epidemics. ${ }^{\mathrm{V}} \quad$ Indeed, the Centers for Disease Control and Prevention reported in 2014 that in twelve states-- Alabama, Indiana, Kentucky, Louisiana, Michigan, Mississippi, Ohio, Oklahoma, South Carolina, Tennessee and West Virginia--the number of opioid prescriptions was greater than the number of citizens. ${ }^{\mathrm{vi}}$ Across Rust Belt America, an alarming number of young men have simply "dropped out" and lack any meaningful social engagement. ${ }^{\text {vii }}$ For those "left behind" there seems to be no clear path forward and, at the same time, no way back to the better days of the past.

Globalization is a historical phenomenon brought about by the heightened interconnectedness of technological and financial innovation taking place across the globe. Globalism is a response to the opportunities and problems that have arisen from globalization. While there is no turning back from globalization, there is considerable disagreement about what globalist policies designed to deal with the opportunities and problems created by globalization should entail. viii For the most part, liberals and progressives emphasize the benefits that could flow from greater cosmopolitanism and international cooperation in solving problems of poverty, disease, climate change and other ills. ${ }^{\text {ix }}$ More radical leftist groups and leaders focus more specifically on the need to right historical wrongs and to redistribute the new wealth that flows from globalization.

Conservatives and libertarians place their emphases elsewhere. They focus on policies to achieve increasingly frictionless capitalism and unrestricted access to free markets. ${ }^{x}$ They seek to create new opportunities for innovators and entrepreneurs and to suitably reward those, who make use of their own skills and energies to take advantage of the new technologies available to all. ${ }^{\mathrm{xi}}$ But there are also some on the right who focus less on future opportunities than on recapturing what they feel they have lost. They see globalization not as an opportunity to create a better future but as a threat to the American and Western European ways of life. As a consequence, they yearn for a return to pre-globalization economic conditions and are susceptible to ominous appeals to reactionary, nativist, or even fascist tropes of the past.

The Nobel-Prize winning work of psychologists Daniel Kahneman and Amos Tversky on the phenomenon of "loss aversion" offers a key to a better understanding of the rise of populism and support for the politicians who encourage and exploit it. Kahneman and Tversky demonstrated that people who have experienced loss, or who are facing the threat of such loss, will undertake relatively risky gambles to restore what they have lost. Their studies illustrated this phenomenon with simple economic gambles ${ }^{1}$, but the relevance of their work to the rise of populism is clear enough.

Throughout history, people who are generous in sharing the economic gains enjoyed in "good times" are far from generous when it comes to sharing the losses imposed in bad times. Many of those in the Western World, including the US, who are suffering a combination of economic loss and assaults on their dignity, status, and optimism about the future have chosen to cast their lot with political leaders who promise to reverse such misfortunes. They are enticed by plans and promises to return to some earlier, more satisfying past (at least as it seen through the rosy glow of nostalgia) or even to build an even more idyllic and ennobling future. To do so, these leaders claim, they need only be given

\footnotetext{
${ }^{1}$ For example, when Kahneman and Tversky presented subjects with the choice between accepting a sure gain of X dollars or gambling on the $50 \%$ prospect of gain of $2 \mathrm{X}$ dollars, they generally opted for the certainty of the $\mathrm{X}$ dollar gain. However, when the decision was to accept a loss of $\mathrm{X}$ dollars or gamble on the prospect of regaining those $\mathrm{X}$ dollars with the possibility of incurring a loss of $2 \mathrm{x}$ dollars, most opted to take the risk rather than accept the certain loss.
} 
enough power to overcome legal and political constraints and to suppress dissidents, trouble-makers, and alien groups who, they claim, are the source of the problems being experienced. Where such leaders have been charismatic, shrewd, and brutal enough to gain the power they sought, the results for the bodies politic that have "gambled" on such leaders (with the dangerously erroneous conviction that "things are so bad they have nothing to lose") have been catastrophic.

Globalization is here to stay, not because it offers all or even the majority a better economic deal or a more fulfilling life, but because it is more economically efficient than its competitors and will drive those who resist it from the neoliberal marketplace. ${ }^{\text {xii }}$ The challenge we face is how to bring about a future that is both politically acceptable and economically and socially bearable (or, ideally, more fulfilling than in the past). This challenge, we believe, is one that neither enlightened liberal or conservative politicians nor radicals at either end of the political spectrum have adequately addressed. ${ }^{\text {xiii }}$

\section{Deep Stories}

What emerges from differing accounts of globalization is a portrait of cleaved societies moving in opposite directions - one toward ever-greater wealth and opportunity and celebration of ethnic diversity and one toward increasing unemployment, underemployment and widespread poverty, with resentment toward immigrants and others willing to work for low pay. ${ }^{2}$ Not surprisingly, the members of those societies produce very different "deep stories" about what is happening to them. These deep stories may not be factually or analytically correct, but the vivid images and symbols they embody capture people's feelings and constitute the prisms through which they view their world. ${ }^{\text {xiv }}$

The deep story of conservative Louisiana, as sociologist Arlie Hochschild tells it in Strangers in their Own Land, begins with standing in a long line patiently waiting for something you call the American dream. ${ }^{x v}$ We paraphrase the rest of the story below:

You are white, Christian, of modest means, probably male, and getting along in years. You wish the others in line well, but you've waited long, worked hard, and the line seems to be barely moving. Suddenly, you notice that people seem to be cutting in front of you. Some are African American, some are immigrants, and some are women. You feel that they haven't paid the dues that you have and are receiving help from the government that you and your family never received. It feels like your place in the line is moving backwards. It doesn't seem fair. You feel abandoned - no, more than abandoned, you feel betrayed.

One of those "left-behind" adds a post-script to Hochschild's deep story: "After a while, the people who were waiting have had it and they get in their own line" (Hochschild, 2016, Kindle Location 2456).

The deep story for those Hochschild calls "progressives" (but she could just as well have identified them as the beneficiaries of globalization) is vastly different. She writes:

"In it, people stand around a large public square inside of which are creative science museums for kids, public art and theater programs, libraries, schools - a state-of-the-art public infrastructure available for use by all. They are fiercely proud of it. Some of them built it. Outsiders can join those standing around the square, since a lot of people who are insiders now were outsiders in the past; incorporation and acceptance of difference feel like American values represented in the Statue of Liberty. But in the liberal deep story, an alarming event occurs; marauders invade the public square, recklessly dismantle it, and selfishly steal away bricks and concrete chunks from the public buildings at its center. Seeing insult added to injury, those guarding the public square watch helplessly as those who've dismantled it construct private McMansions with the same bricks and pieces of concrete, privatizing the public realm." (Hochschild, 2017, Kindle Locations 3887-3897)

Both of these deep stories are about community and fairness. However, they offer vastly different accounts of what is going on. ${ }^{\text {xi }}$ Cosmopolitan America looks to government to promote a rich, thriving multicultural environment, as

\footnotetext{
2 The perception of white worker that they are losing out to minority workers is not without some validity. Eduardo Porter, an economic columnist for the New York Times, reports:
}

"There are almost nine million more jobs than there were at the previous peak in November 2007, just before the economy tumbled into recession. But the gains have not been evenly distributed.

Despite accounting for less than 15 percent of the labor force, Hispanics got more than half of the net additional jobs. Blacks and Asians also gained millions more jobs than they lost. But whites, who account for 78 percent of the labor force, lost more than 700,000 net jobs over the nine years.

The racial and ethnic divide is starker among workers in their prime. Whites ages 25 to 54 lost some 6.5 million jobs more than they gained over the period. Hispanics in their prime, by contrast, gained some three million jobs net, Asians 1.5 million and blacks one million." (Porter, 2016) 
something to be treasured and celebrated as consistent with our history as a nation of immigrants. The other America sees multiculturalism and government measures that regulate business, impose environment protections, and subsidize the neediest as interferences in their communities and their lives and as symptoms of societal decline. The more sophisticated opponents of such progressive, neo-liberal policies argue that laissez faire capitalism, whatever its limitations, has the virtue of promoting self-reliance. If America would simply return to its pre-global political and cultural foundations, they claim, it would become "great" again. At least, they hope it would and they are willing to gamble (and urge those left behind to gamble) on leaders who, while unsavory in some respects, nurture that hope. ${ }^{3}$

\section{Rivals or Enemies}

The presence of competing deep stories need not be problematic. Indeed, the tension between different perspectives can promote innovation and problem-solving. Serious problems, including potentially violent confrontations, arise when the rival factions telling and living out these stories come to see themselves not merely as political competitors but as enemies. The transformation from rivals to enemies, or vice versa, as we shall elaborate later in this paper, depends upon the answer to a simple question: What would happen to me/us if "they" got what they really wanted, if the other side got to call the shots?

The tensions embodied in such polarized standoffs create a state that is often termed a "post-conflict" situation, but we

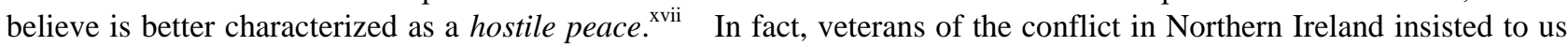
that the status quo was not a "post-conflict situation"--for the conflict continued; it was not "post-anything." Beneath the calm surface, there remained a molten mix of disagreements that threatened to erupt at any given moment, and the persistence of a zero-sum struggle. Aware of that potential eruption, the parties feel that the only guarantee an acceptable future is the capacity to prevail over the opposing side. Such sentiments could be heard in the explanation offered by a North Belfast loyalist for why she was out early on a damp, cold Ulster morning defending her right to march on the "Queen's highway." xviii Raising her arm, she pointed at a protesting group of Belfast republicans and said, "Well, if we don't [march], the other side will take over." Her energies were focused not on some specific positive goal-her marching was not designed to help her fellow loyalists achieve some particular end-state or change in policies, but rather to oppose and frustrate the aspirations of her "enemies." 4

Mediators seeking to ameliorate conflicts (and the social scientists who advise them) emphasize the importance of superordinate goals. ${ }^{\text {xix }}$ Many see such goals as the royal road to improved relations and ultimately to a genuine and durable peace. Our personal experiences in conflict resolution and dialogue promotion suggests otherwise. The dynamics of a hostile peace do more than block that royal road; they make all negotiations, beyond those designed merely to end or avoid bloodshed, zero-sum propositions. Third parties can point to, or even incentivize, superordinate goals for the parties to pursue together, but enemies fear that anything the other side proposes or agrees to would be a step in the direction of an unbearable future. Relational concerns, rather than terms of agreement, we believe, must be the starting point in the pursuit of lasting peace.

\section{SCICN's Four-Question Framework for Addressing Intractable Conflicts}

The barriers analysis ${ }^{\mathrm{xx}}$ developed by the Stanford Center on International Conflict and Negotiation (SCICN) began with the simple question: What stands in the way? That analysis identified a number of strategic, structural and psychological barriers that thwarted efforts to achieve agreements to end long-standing, seemingly intractable conflicts. The most formidable barriers we personally encountered in our intervention efforts were created by, and were exacerbated by, the state of relationships between the parties. In light of that real-world experience, we eventually formulated a set of four questions to help parties appreciate, and to some degree redefine, the relational obstacles to be overcome in reaching mutually acceptable resolutions to ongoing conflicts.

Our four-question framework had its origins in our conversations with Community Dialogue leaders in Northern Ireland almost twenty years ago. Started in 1997 by citizens seeking to bridge the divisions between their deeply polarized communities through frank citizen dialogue, these forward-thinking activists recognized that, whatever the details of

\footnotetext{
${ }^{3}$ In The Left Behind, Robert Withnow writes: "The moral outrage of rural America is a mixture of fear and anger. The fear is that small-town ways of life are disappearing. The anger is that they are under siege. The outrage cannot be understood apart from the loyalties that rural Americans feel toward their communities. It stems from the fact that the social expectations, relationships, and obligations that constitute the moral communities they take for granted and in which they live are year by year being fundamentally fractured." (2018, Kindle Locations 105-109).

${ }^{4}$ We heard similar sentiments from workshop participants from African nations describing the hostile, and fragile, relationships between people within their own societies. Each side believed that it confronted a "do or die" situation in which they must crush the aspiration of the other or face annihilation. Given that conviction, few believed that talking with the other-or any other form of constructive "engagement" — would serve any useful purpose.
} 
any forthcoming formal agreement, the existing relationships on the ground between the unionist/loyalist and nationalist/ republican communities would neither sustain the deal nor allow a better future to emerge. ${ }^{\mathrm{xxi}}$

In initial meetings between citizens from those communities (which, on occasion, included SCICN observers), Community Dialogue initially posed three simple questions to the participants:

(1) What do you want?

(2) Why do you want it?

(3) What can you live with, given that other disagree ? $^{x \times i}$

While vigorous and engaging, and a step forward from hostile actions and reactions, the resulting dialogue eventually proved frustrating for all concerned. After two years, the dialogue seemed stuck in place, spinning around an ever-increasing set of contentious issues in which everything seemed related to everything else. Like spouses in a bad marriage, when faced with difficult questions or decisions that would require mutual compromise, the parties tended to change the subject and engage in recriminations. Four themes, however, seemed to be recurrent, and we found that structuring the dialogue explicitly around those themes helped give direction to the dialogue without limiting the parties' ability to express their concerns and aspirations.

First, while the past is never far below the surface in Northern Ireland, the prevailing concern and deep anxiety was about the future and what it held for them and their community. Uncertainty about their future, and particularly the prospect of unbearable outcomes if the other side began to control events, posed a barrier to constructive engagement and discussion of potential trades of concessions.

Second, there was a pervasive dis-ease hovering in the background of dialogue as the parties exchanged views and floated proposals, which was rooted in distrust. The parties feared, not without some justification, that, if the other side gained the upper hand at any point in the future, it would reassert their earlier, maximal demands.

Third, as a war of words replaced bombings and other forms of violence, the parties increasingly felt that the concessions, both material and symbolic, that they would be called upon to make (in contrast to the ones they sought from the other side) entailed losses too painful to bear.

Finally, while the parties shared the desire for a peaceful future, both felt entitled to a post-conflict arrangement that would give them not only an improvement over the current status quo, but justice. Both sides insisted that they sought nothing more nor less than what they felt entitled to receive in light of what had gone before and what was required for the type of future they rightly sought. Hearing the other side voice that aspiration, in turn, stoked each side's fear about whether they could trust the other side to abide by the agreement if and when they found it possible and expedient to do otherwise.

The four core themes that we identified could be summarized in four questions:

1. Are the parties willing and able to envision a shared future?

2. Are the parties willing and able to take the steps required to create trust about motives and longer-term goals?

3. Are the parties willing and able to accept painful losses and acknowledge that the other side will accept similar losses that are no less painful?

4. Are the parties willing and able to accept what they believe is less than ideal justice and work together to rectify the most egregious injustice that living together in peace will impose?

In a sense, the primary challenge in peacebuilding as embodied in that four-question framework is the transformation of an enemy relationship into one that is merely adversarial and that allows disagreements to be settled and objectives achieved through normal political processes and legitimate institutions. This approach essentially reverses the sequence of steps embodied in the standard interest-based negotiation or "getting to yes" approach whereby the parties are prompted to trade things that they value less than their opponent for things that they value more than their opponent in a way that advances the interests of both parties relative to the current status quo. ${ }^{\text {xxii }}$ Things that might prevent or impede such mutually beneficial trades, including bases for claims and grievances, are to be set to the side in this approach so that the parties can explore new and/or different ways to pursue their underlying interests without making demands that create deadlocks.

Our experience with longstanding, bitter conflicts—particularly those in which blood has been spilled—suggests that considerations of the sacrifices endured, mistrust and distrust about the future, failed or frustrated aspirations, and the 
just entitlements denied, are not easily "set aside." Our four-question framework becomes most relevant when this "getting to yes" approach produces not an exchange of "efficient" trades and compromises but mutual recriminations about who is responsible for the stalemate. The working assumption in this approach is captured by the proposition: It is not that agreements produce peaceful relationships but that peaceful relationships produce agreements. The four-question framework is essentially a way of getting to "getting to yes." It functions not only as vehicle for a new dialogue but also as a lens through which problems can be viewed more constructively and new possibilities envisioned.

We have sat across from political and community leaders countless times and listened to them describe the problems and issues they face, making note of what we were hearing. Generally, we heard little about the place of the other side in the future being sought, quite a bit about problems of trustworthiness, even more about the losses that one or the other party had suffered and would suffer if the other party got its way, and opening, continuing, and closing appeals to justice.

\section{Elaboration of the Four Questions}

1) The question of a shared future: Are the parties able and willing to articulate a future for the other side that it would find bearable?

No substantial progress toward stable politics is possible unless both parties feel that it could live a reasonably tolerable existence if the other side's basic aspirations were realized. The vision of a shared future is not necessarily a shared vision of the future. Disagreement about specific policies, institutions, and political arrangement are bound to persist. Indeed, the future that one or both sides seek may be far from what the opposing side wants or would deem fair. But each side must recognize the need to consider and articulate the place the other side will hold in the future it seeks. Furthermore, both sides must communicate their vision to the other side, with an awareness that if the other side does not deem this future tolerable - if it does not offer dignity and a lifestyle that is, at least, no worse off than their present one - no amount of persuasion or appeals to principle are likely to bear fruit. This question is the most fundamental one, and unless addressed, negotiations, or even attempts to create good will, are bound to be a futile exercises. ${ }^{5}$

2) The question of trustworthiness: Can the two sides trust each other to honor commitments and to take the intermediate steps necessary toward that shared future?

In the context of longstanding conflict, each side feels that the other bears responsibility for the onset of the conflict, has broken past promises, and otherwise proven unable or unwilling to make the types of difficult compromises necessary for progress toward a settlement. Given these sentiments, both sides face a critical question: Why should we now trust you? What has changed to make things different? Both parties need to be convinced that there is now some new basis for trust. Typically it involves seeing some new awareness on the part of the other side, or perhaps some change in circumstances, that allows one side or both to believe that the other side is now willing to agree to and honor, even if not unreservedly embrace, terms it previously has rejected. Hearing the other side propose a future in which one is offered a bearable place - and above all seeing the other side act in a way that suggests it accepts that vision of a shared future - can be that change.

3) The question of loss acceptance: Can the parties accept the losses that a settlement will inevitably impose on them; are they truly ready to make the necessary compromises, including ones that they said they never would make?

A mutual sense of loss pervades the aftermath of virtually every negotiated peace agreement. This is because a genuine peace achieved by negotiated agreement, as opposed to one achieved by outright victory, demands an abandonment of the hopes and dreams that fueled the conflict and that allowed the parties to reduce their dissonance about the price they were paying in that conflict. Both sides, furthermore, are bound to feel that it is the side making the more painful and difficult concessions while the other side is surrendering nothing of consequence - certainly nothing to which it was ever entitled. One important purpose served by meaningful dialogue prior to agreement is that it can help both sides come to appreciate the extent to which the concessions being made by the other side for the sake of peace are truly painful - that the other side's concessions, no less than those of their own side, represent the abandonment of cherished hopes and dreams.

4) The question of just entitlements: Can the parties work to accept an agreement that does not meet what they perceive to be the requirements of justice. Also are they willing to work together to alleviate or rectify the most serious

\footnotetext{
${ }^{5}$ In our citizen dialogue experience in Northern Ireland we have found it useful to begin by requiring each side to present the other's views to the satisfaction of that other side. This process, which invariably produces false starts and frustrated efforts as each side tries to satisfy the other side that its position has been accurately articulated, helps avoid straw-man arguments. As a "bonus" the process of hearing the other side struggle and ultimately succeed in this task, and engaging in the same struggle themselves, builds respect and empathy between the participants.
} 


\section{injustices that might otherwise remain in the aftermath of agreement?}

Every negotiated peace agreement imposes not simply losses, but unjust losses on some, if not all, members of both parties. The goal of reaching a settlement that is deemed to be just by all of the different constituencies comprising the two sides is an impossible one to achieve. The question therefore is not whether the agreement is truly just for all concerned - it will not be - but whether the parties feel that the injustices the agreement imposes are bearable. No less important, both parties, and especially those constituencies within each party that could become "spoilers," must come to feel that the benefits of the peace at hand are likely to outweigh the injustices it imposes on them. The challenge facing both parties is to work together to make the answer to this question be yes. Meeting this challenge requires them also to work together to address the needs of those most likely to be adversely affected by the terms of that peace. Justice may be beyond the reach of mere mortals, but agreement to rectify the most egregious injustices is not beyond their reach.

\section{The Challenge of Globalization: Shared Visions of the Future versus Visions of a Shared Future}

How does four-question framework, with its specific focus on the articulation of a bearable shared future, apply to the challenges of globalization and the strains on the bonds that hold Americans together? What can be done to strengthen those bonds in the way that would facilitate efforts to create such a future? We believe a starting point for this discussion is the conviction that Americans have obligations to each other, and particularly to those whose lives are most difficult and whose needs are not being well served. While the precise debts and duties are subject to debate ${ }^{\text {xxiv }}$, and the amount of face-to-face engagement that is most desirable may differ in different communities, all Americans share an obligation to work (at least metaphorically) shoulder-to-shoulder toward "a more perfect Union."

In The Once and Future Liberal, Mark Lilla claims that America has not had a broadly agreed upon set of political goals for at least two generations. What it is has had, instead, are two exhausted ideologies - mainstream liberalism and mainstream conservatism - that today are "intrinsically incapable of discerning the common good and drawing the country together to secure it" (Lilla, 2017, p. 99). Lilla goes on to emphasize three priorities in any efforts to formulate a shared vision for our country: (1) "the priority of institutional over movement politics", (2) "the priority of democratic persuasion over aimless self-expression," and (3) "the priority of citizenship over group or personal identity" (p. 104). In a forthcoming book, Francis Fukuyama is more specific. He claims that what is required is a shared "creedal" identity, and the creed he feels must be embraced is the one embodied in our Constitution and Bill of Rights. That identity also demands the embrace of traditional American values that honor hard work, celebrate the success of immigrants and their children, and accept the full responsibilities of citizenship and community membership. ${ }^{\mathrm{xxv}}$

These prescriptions, pit traditional economic and class politics against the rising tide of identity politics. ${ }^{\mathrm{xxv}}$ We shall have more to say later about difficulty of building coalitions not only across this political divide within liberal and conservative political circle. For now, we will merely introduce a distinction that foreshadows this discussion - the distinction between the vision of a shared future and a shared vision of a specific future.

Parties arrive at a shared vision for a specific future, and terms of agreement to realize that vision, through the give-and-take of compromises and concessions designed to maximize joint benefit. The success of such negotiations depends upon the sharing of an overarching objective, although some more specific objectives may not be shared. However, each party recognizes the goals of the other to be legitimate aspirations. Each party expects the other to continue to pursue its separate goals but to do so only through political means rather than coercion or violence. It further assumes that the parties are committed to work together and honor any future agreements they reach.

The vision of a shared future, by contrast, does not presuppose agreements about overarching goals or even the legitimacy of existing political processes. What is mainly required is the simple recognition by the parties that they must live together and that, despite discord and disagreement, their futures will include each other and must be mutually tolerable. In discussing the notion of a hostile peace, we suggested the question each party wrestled with was what would happen to us if they got what they really wanted. The central issue at play in the notion of a shared future is the willingness of the parties to address the converse question of what would happen to them if we got what we really wanted - whether they feel that they would be able and willing to live with the future that we are offering.

During a contentious political meeting in Belfast between unionist/loyalist and nationalist/republican factions, one of the participants took the stage to ask his counterparts where was he in the future to which they aspired. What place did they intend to afford him and his culture, and what role would he and his compatriots be allowed to play in determining that future? The questions he raised needed to be addressed. But the opposite question - the place and power of his adversaries in the future that he and is side envisioned - also needed to be addressed. In the course of our initial citizen-dialogue work in Northern Ireland and other sites of longstanding conflict, we came to realize how seldom the articulation of a place for the other side took place without our intervention. Continual prodding was necessary. False starts whereby the participants reverted to discussing their aspirations and to offering reasons why they thought those 
aspirations were both legitimate and just were a constant challenge.

The meaning of bearable in our posing of the shared future question is obviously problematic. What counts as bearable is subjective, circular, and subject to change as events on the ground unfold. After a contentious unionist march through a Catholic community in Northern Ireland, we walked with our colleague Fr. Brian Lennon while taking the pulse of grassroots republican sentiment. What we heard was unanimous rejection of the prospect of an IRA ceasefire unless and until there were changes in the ongoing "unbearable" political situation. Two weeks later, when Sinn Fein announced a ceasefire, it quickly won the overwhelming support of its constituency. In a head-spinning turn of events, what had been deemed unbearable became quite bearable when the leadership of their community, heralded the agreement as a step toward eventual empowerment.

The term bearable when applied to a set of political and social arrangement shares the ambiguity and circularity of the term hurting in the notion of a hurting stalemate. As many critics have noted, it is impossible to specify in advance when a stalemate turns (or ceases to be) hurting. Only in retrospect, after a settlement has been reached, can we ascribe the adjective hurting to a stalemate. Conversely, when negotiations fail to produce agreement, it is too easy to maintain that the stalemate is not yet hurting enough.

\section{The Challenge of a Shared Future in a Globalized America}

For many of the white working-class, the future they hope for would be a return to a past that afforded them both good jobs and the dignity and self-esteem tied to those jobs. However, disadvantaged members of minority communities - even those who labored alongside white workers, shared union membership with them, and often broke bread with them-found that past less satisfactory. Many African Americans and Latino factory workers whose good-paying jobs disappeared have reservations about the re-creation of a past where they lacked full social rights and economic opportunities. Both white and minority group workers, however, share the fear that jobs and prosperity will not return, and both seek ways to provide for their families and lead meaningful lives.

The problem is that many white workers have come to see minority aspirations for greater equality (as well as immigrants' hopes to find a better future in America) as a threat to their own well-being. In their anger and frustration they search for scapegoats. ${ }^{\text {xxvii }}$ Minority workers, in turn have reacted with understandable distrust to what they see as an indifference, if not racist hostility, to their calls for greater social and economic equality. The sense of class solidarity and common purpose, which was enhanced by shared work demands and encouraged by shared union membership, has largely been lost.

Daunting racial and political realities aside, the prospects for an economic future that satisfies those now "left behind" seems dim and distant. ${ }^{\mathrm{xxviii}}$ While there is much room for debate, there appears to be an emerging consensus among experts that mass employment in manufacturing, as we have known it in the past, is not coming back. ${ }^{\text {xix }}$ The optimistic assumption that globalization will eventually produce net increases in wealth, and the further assumption that such an increase in wealth will produce net increases in economic demand, may prove accurate. However, those increased demands are unlikely to benefit factory workers in America's heartland. ${ }^{\mathrm{xx}}$

The rise of artificial intelligence and ever more sophisticated innovations in automation promises few new jobs for those without college educations and, for millions, no job prospects at all. ${ }^{\mathrm{xxx}}$ Beyond uncertainties regarding the future job market, our society faces the prospect of ever-increasing concentration of wealth and political influence in the hands of a small number of individuals. ${ }^{\text {xxxii }}$ Economists further predict that gigantic firms will probably dominate the global internet market, exacerbating the gap between "haves" and "have-nots" both within US society and internationally. ${ }^{\text {xxxiii }}$

These trends make the envisioning and pursuit of a bearable shared future, not only for Americans but for the world, a challenging task. Further daunting challenges will arise in the search for accord about trade and immigration, to say nothing of the need to address climate change and other environmental concerns. The details of economic arrangements that might be acceptable both to America's various communities and to nations with differing immediate needs and circumstances, resources, political institutions, cultural values, and traditions is far beyond the scope of this paper. What we shall focus on is the relevance of the four-question framework to these challenges.

\section{Building Commitment for the Pursuit of a Shared Future}

The four question framework begins with the need to envision a mutually bearable shared future, and then proceeds to consider three specific needs and challenges - creating trust, accepting losses, and foregoing demands for full justice - that must be met if such a vision is to be developed and accepted.

\section{Trust, and Trustworthiness: Lessening Fears and Offering Respect.}

On more than a few occasions, colleagues involved in peace-making and conflict resolution have told us that the most 
difficult task they faced was that of creating trust between the adversaries. While trustworthiness is sometimes seen as a character trait of individuals, people more commonly trust or fail to trust particular individuals to do particular things in particular situations. In conflictual situations, parties who speak of the need for trust want assurances that the other party will abide by the agreements they make, "come what may". (At the same time, we have found, each wants to reserve their right to revisit and even renege on agreements should circumstances change and the need for new terms of agreements become evident.)

Standard accounts of trust in the conflict resolution literature offer limited help in our discussion here. ${ }^{\text {xxxiv }}$ Most treat trust as the product of a calculation that culminates in the confidence that the party with whom one must enter into an agreement will keep a promise. But deeper levels of trust involves more than a calculation or prediction, they involves a sense of commitment to an ongoing relationship characterized by mutual respect, and an assumption that future disagreements will be resolved through discussion and compromise rather than force or arbitrary actions. Russell Hardin's notion of trust as encapsulated interests nicely captures this aspect of trust when he writes:

"I trust you because I think it is in your interest to take my interests in the relevant matter seriously in the following sense: You value the continuation of our relationship, and you therefore have your own interests in taking my interests into account. ... [Y]ou encapsulate my interests in your own interests"

(Hardin, 2002, p. 1)

Trust does not demand feelings of personal closeness or even sympathy. However, it does demand mutual recognition of the overlapping, linked, and embedded characters of one's own and the other party's interests. In The Problem of Trust, Adam Seligman argues that when trust disappears, the risks attending social relationships becomes a source of danger. ${ }^{x x y}$ The danger that those who feel left behind by globalization, and believe that our country is heading downhill, fear most is falling down the social and economic ladder. ${ }^{\text {xxxvi }}$

Even those who continue to have jobs, intact families, and relative stable community relations, see their way of life is slowly unraveling before their eyes. ${ }^{x x x v i i}$ Only $24 \%$ of white Americans, Seligman notes, currently believe that their children will be better off financially than they are. ${ }^{\text {xxviii }}$ They feel abandoned and betrayed by what America is becoming. They look down the pecking order and see problems that they thought themselves immune to. Their fear is that, "if we don't turn this things around, those outcasts and downtrodden will be us."

Such fear has two components. First, there is fear of the economic problems that being left behind will actually cause. The consequences in question are real and often severe. The second component is essentially social and political. It is the fear of being abandoned, of having no trustworthy partner to whom one could turn for help. Those left behind no longer believe that their interests and those of the global elite are encapsulated. Our concern here is more with the political aspect of the fear gripping those left behind. Aristotle claimed that the city (polis) embodied more than commercial relationships. It consisted of friends who were concerned about each other's welfare, who made, the deliberate decision to share their lives for the purpose of living well. ${ }^{\text {xxix }}$ Implicit in this claim is the idea of mutual respect.

Hannah Arendt thought that respect, as it pertains to the addressing of problems of mutual concern, is akin to what Aristotle meant by philia politike or political friendship. ${ }^{\mathrm{xl}}$ Respect is a regard we have for people that is not dependent on the qualities and achievements that we admire in them. Arendt maintained that "the modern loss of respect, or rather the conviction that respect is due only where we admire or esteem, constitutes a clear symptom of the increasing depersonalization of public and social life" (1958, p. 243).

Even after Arendt's clarifying insights, respect remains a slippery concept. Margalit suggests that it includes recognition of people's capacity to reevaluate the way they live and act and to make changes where warranted. ${ }^{\text {xli }}$ Of course there are beliefs we may not deem worthy of respect, but that doesn't mean that the individuals holding and acting on those beliefs are unworthy of our concern. Not everyone has the same aptitude for moral introspection and people differ in their capacity to break with their past or change the way they live. But respectful engagement should always be the first strategy to consider in the face of disagreement,

Let us be more specific and personal here. Both of us consider ourselves progressives, but we are dismayed when we hear our liberal colleagues be dismissive of conservative arguments and especially when they hold forth against mere caricatures of those arguments. Conservative contentions, even some populist complaints, should be heard, and the analyses of the ills of contemporary society offered by thoughtful conservatives should be taken seriously and addressed respectfully, even if we ultimately reject the nostrums they suggest to deal with those ills. Taking seriously does not mean agreeing. But it does demand that we acknowledge the authenticity of the perspective being presented and that we try to understand what lies behind it. What we must always treat as authentic are the lived experiences of those we are engaging, and the lessons they claim to have drawn from such experiences. Doing so is the first step toward, and 
ultimately the sine qua non of, respectful engagement.

\section{Loss Acceptance: Safeguarding Livelihoods}

All negotiated agreements impose losses on some members of the parties. The price of an agreement to end a conflict (and realize whatever material gains that agreement offers) is the inevitable forgoing, for some, of hopes and dreams. Moreover, as we noted earlier, the losses that one's own side has had to accept feel difficult and painful, while those imposed on the other side feel insignificant and inconsequential - the loss of things, in fact, to which they never were entitled. Having both sides come to a greater appreciation of what the other side has had to give up, which can include not only hopes and dreams but also the rationalizations that have been used to justify the cost and sacrifices endured during the struggle, can pave the way to more empathetic and more positive relationships.

Americans left behind by globalization and automation have experienced painful losses and face the prospect of further losses in future. They should not be called upon to passively accept such losses. Engaging in collective political protest and actions to improve the circumstances under which one lives is not only an inalienable democratic right, it is a source of self-efficacy and self-respect. Wise social policies should reduce the risk of the loss of a decent standard of living in economic terms. However, they should also reduce the risk of a future lacking in dignity-including the dignity that comes with the loss of one's community or the loss of standing within one's community. ${ }^{6}$

As Margalit argues in A Decent Society, people need an adequate and reliable income to maintain self-respect. But

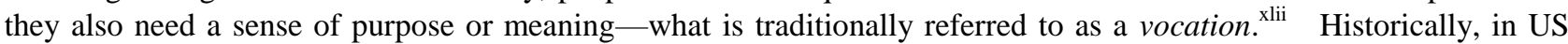
society, employment has served both to provide livable incomes and the contexts within which a sense of vocation is played out. The ripple that runs through retail and small businesses when a major manufacturing plant closes, as many social scientists and journalists have described, is devastating. ${ }^{\text {xliii }}$ The problem we now face in Rust Belt America as good paying jobs disappear is not only how to safeguard decent standards of living, but also how to safeguard opportunities for people to engage in activities that give meaning to their lives. ${ }^{7}$

It is doubtful, at least in the short run, that market mechanisms alone will restore prosperity to America's hinterlands. Neil Irwin, a New York Times economist, argues that the US has already paid the costs demanded by globalization and should now make sure that it pursues policies that allow its citizens to reap the benefits. ${ }^{\text {xliv }}$ Even if such benefits materialize, there remains the question of whether market mechanism will distribute these benefits in a manner that will serve heartland America. Increasingly, sophisticated forms of automation that increase profits and wealth will probably limit the number of jobs that are actually created. ${ }^{\text {xlv }}$ As a consequence, wealth transfers will almost certainly be required not only to maintain standards of living but also to fuel the purchasing power of those Americans who do not directly benefit from globalization.

The question of how to accomplish these transfers of resources in ways that are deemed legitimate, or at least tolerable, to those whose wealth is being transferred and at the same time non-humiliating to the beneficiaries of that transfer is a question worth further consideration. ${ }^{x l v i}$ What is at issue is more than the facelessness and inhumanity of bureaucracies, with their indifference to the plight of those forced to rely on economic safety nets and other protections that modern societies feel compelled to provide. For many, perhaps even most Americans, reliance on safety nets and social welfare programs is for "losers"- for people who can't or won't "pull their weight", for "takers" rather than "makers." "xlvii

In The Left Behind, Wuthnow writes: "Rural communities are places of moral obligation" (Kindle Location 204). First order obligations, he claims, are to oneself and one's family, so that one is not a burden on one's neighbors. Further obligations - some more optional and selective-extend to a wider web of relationships that support communal life. Against this background, it is easy to see how aid recipients who are neither disabled nor temporary victims of natural catastrophes are seen as lazy non-contributors to their communities and to the larger society.

Whereas the failure to provide for one's own well-being is an indictment of one's talents and motivation, the failure to contribute to one's community and occupy a dignified place within that community constitutes an unbearable indictment of one's character. In describing the Protestant ethic, Max Weber famously argued that dignity arises not

\footnotetext{
${ }^{6}$ In Left Behind, Robert Wuthnow notes: "Talking to rural Americans, you learn quickly how deeply their identity is rooted in their town. Its population may be declining, but they care about its survival. It is where they know people - their neighbors, the mayor, the woman at the bank, the man at the farmers' co-op. Maybe they grew up here. Maybe they own land. They care if the home team has a winning football season. They take pride in their community spirit." (2018, Kindle Locations 99-102).

${ }^{7}$ We cannot resist noting that those in the upper reaches of society who do not hold real jobs but benefit from great family wealth rarely feel that their situation is "undignified." Nevertheless, many do seek pursuits that give them a sense of identity, for some as sportsmen or hobbyists, but for some as public benefactors and activists for social or political causes they deem worthy.
} 
from the industriousness of work itself but from the sense that one is living a worthy and meaningful life-from the sense of vocation or calling that God has commissioned. ${ }^{8}$ While the notion of religious calling has diminished since Weber's time, for most Americans, their identities and sense of social worthiness continues to rest heavily on their job or occupation.

In Habits of the Heart, Robert Bellah and his colleagues built upon Tocqueville's observation about the American penchant for community involvement. Tocqueville thought that "the experience of getting involved in local volunteer civic associations was itself capable of generating a sense of responsibility for the public good” (1985, p168). For Bellah, as for Tocqueville, the vector of responsibility runs from the individual to the community. The reverse is also true: engagement in community activity leads participants to take responsibility for the individuals served by that activity. Martin Luther King, Jr., in the preface to Strides toward Freedom, wrote that the marchers who engaged in the struggle to gain their freedom "acquired a new estimate of their own human worth" (1958, p xxix). The struggle to safeguard dignity for those left behind by globalization, we believe, is a shared responsibility. Participation in that struggle does more than fulfill an obligation, it can reinforce the sense of person worth for all concerned.

\section{Satisfying Demands for Justice versus Fostering Dignity}

The four-question formulation we described earlier holds that while justice is a necessarily component of any lasting settlement, prioritizing the immediate pursuit of justice, especially justice for all, is a barrier too high to clear. Instead, we suggested, the parties would be better served by working together to rectify the most egregious sources of injustice that exist or that would be inflicted by the terms of any agreement that is feasible and efficient. For example, ending one group's monopoly on jobs in a particular public or private sector may demand the displacement of workers who have done a good job, and who have made life choices assuming their jobs would continue. There may be no way of avoiding such job losses, but both fairness considerations and the need to reduce opposition to the relevant agreement can be served by providing generous pensions for workers approaching retirement age. Special retraining and placement assistance, especially for younger workers, and some creative thinking about creation of new job opportunities that would utilize the displaced workers' skills would further serve those goals.

In Strangers in Their Own Land, Arlie Hochschild observes that both the right and left in the US "call for an honest day's pay for an honest day's work" (Hochschild, 2016, Kindle location 2529-2530). For many who have come to support the Republican Party, especially those we label as populists, the unfairness that exists in the US is rooted in "makers" versus "takers" - those who work hard and support themselves and their families (or seek only a chance to do so) versus those who line up local welfare offices, receive undeserved disability checks and government assistance, and otherwise "game the system" to avoid working to earn an honest living. For many Democrats, especially those in the left wing of that party, unfairness in America today is rooted in the current distribution of the economic pie. They note that globalization and automation have hugely increased the share going to those in corporate boardrooms and executive offices at the expense of those who are struggling to make ends meet. The flashpoints of conflict for those on the right are between the struggling middle class and the poor. For those for the left, the focus of discontent involves the disparity in wealth and political power between the $1 \%$ at the very top of the economic ladder and the other " 99 percent", especially those at the lowest rungs of that ladder, and those whose race has prevented them from rising on that ladder.

Many who support the progressive agenda of the Democratic Party, occupy the rungs just below that top 1\%. They are the "next 9\%" whose incomes have risen sharply in recent years and whose share of the economic pie has increased. xlviii This group includes professors and professionals, engineers, and others whose special skills are well compensated and are able not only to provide well for their families, but transmit the social capital that will allow their children to follow in their well-heeled footsteps. Ironically, it is they, rather than the top $1 \%$ to whom the anger of those left behind is most often directed. Many white working class Americans feel that they have been abandoned and ignored by coastal elites who are more concerned with social issues and the righting of past civil wrongs than with the economic plight of their fellow citizens and the destruction of their way of life.

Rectifying the many sources of grievance and conflicting claims of the aggrieved in American society, may not be possible in today's political climate. Rather than pursuing that elusive goal, Avishai Margalit suggests the more reachable and morally appropriate goal of a "decent society."xlix Such a society, he claims, is one that does not humiliate its members and affords dignity to all. While just societies must be decent, Margalit suggests that societies

\footnotetext{
${ }^{8}$ Prior to the rise of Protestantism, religious devotion involved a rejection of the affairs of the world. Weber argued that, when Protestantism challenged the formula for salvation offered by the Catholic Church, its adherents began to look elsewhere for signs of their salvation. Worldly success, he claimed, became one of those signs, and Protestants began to pursue not only worthy secular vocations, but also the accumulation of wealth, with almost fanatical zeal (Weber, 2002).
} 
can be decent without satisfying all legitimate claims for justice. He rejects the metaphor of climbing a mountain whereby justice lies at the summit and decency is a way-station below the summit. Instead he suggests that we envision ourselves as amateur pilots who want to fly to the idyllic Hawaiian Islands from somewhere in the heartland of America but don't have fuel to get there. Getting as close as possible before the fuel runs out would leave us in a downed plane somewhere in the middle of the Pacific. A better plan would be to fly to Miami-not quite the tropical paradise we hoped for, but a pretty good place to escape the winter! Margalit does not suggest that we abandon the goal of a just society - we can continue to dream about and save our dollars for that trip to Hawaii-only that we not let that goal keep us from pursuing and achieving the more modest goal of a decent society.

The ideal of justice as fairness is an idea that has long dominated discussions of distributive justice. It was offered with particular force by John Rawls in A Theory of Justice. $\quad$ There, he suggested that we need to give special attention to the perspectives of the less powerful. His famous thought experiment asks us to place ourselves behind a "veil of ignorance" as to our potential ranking in the society as we consider the fairest and most appropriate distribution of wealth. Given that task, Rawls submits, we would opt for moderate rather than huge discrepancies between the most and least favored.

Psychologists are skeptical about the usefulness of Rawls thought experiment. They cite the "bias blind spot" that leads people to imagine that their current perspectives are already objective and to feel that they are immune to the self-serving biases that affect others. Economically favored Americans today are all too able to rationalize the gap between their circumstance and the circumstances of their less fortunate compatriots. ${ }^{\text {li }}$ Also, when asked about the ideal distribution of wealth in their country, most respondents express a preference for unequal outcomes that give weight to the merit of claims over outcomes that arbitrarily impose equality. ${ }^{\text {liig }}$ Nevertheless, in accord with Rawls claim, researchers find that most Americans, when given the choice, endorse a distribution of wealth that is far "flatter" than the one that exists today. In fact, the ideal distribution described by this representative sample of Americans was dramatically more equal than exists anywhere in the world. ${ }^{\text {liii }}$

In the context of globalization and globalist policies, those left behind feel that their past efforts and sacrifice have not be fairly acknowledged and taken into consideration. In A Hillbilly Elegy, J. D. Vance asserts that the American Dream disappeared in his community when it failed to provide a steady wage. ${ }^{\text {liv }}$ On closer examination, however, his narrative may have less to do with the loss of material comforts than with the humiliation created by the lack of a steady wage. ${ }^{10}$ When people are afforded dignity and respect, they may or may not accept unequal outcomes (depending on how much that inequality violates their sense of fairness). But they will pointedly resist unequal outcomes that undermine their individual dignity and their collective identity as members of a community that is worthy of concern and respect.

\section{Populism as a Threat to the Pursuit of a Shared Future}

Jan-Werner Muller characterizes populism as a political ideology that sets a pure and unified people against dangerous outsiders. ${ }^{\text {lv }}$ These outsiders include not only immigrants and ethnic or racial minorities, but in many cases also cultural and economic elites whom populist leaders label as corrupt or morally inferior. The foundation of populism is the identification of a hardworking, innocent, wholesome group characterized as "the real people" who now must struggle against all who would undermine their way of life. Casting aside facts, it speaks of a greatness and purity that once was, and is now to be restored. In short, populism mobilizes a Manichean worldview in which absolute good opposes absolute evil. For a minority of Americans, but by no means a small minority, the US and the West more generally is in a fight for survival in which nothing short of the total annihilation and banishment threatening, evil "other" will constitute victory.

Populism, Muller interestingly claims, exists only in the context of representative government and majoritarian elections. As such, it is democracy's "permanent shadow." "lvi Populist candidates test the will of the electorate, but populism involves more than an effort to win majority support for leaders who espouse populist aspirations. It claims special license as the authentic and unambiguous expressions of the "real people's" will and acknowledges no responsibility to take into account the diverse claims and aspirations that compete for support in any true democracy.

\footnotetext{
${ }^{9}$ However it is worth noting both the popularity and the perceived legitimacy of programs that offer equal tax-funded benefits (including social security payments, health care, access to recreational or educational facilities) to rich and working-class alike, even when those programs are supported by progressive taxation of wealth and/or income.

${ }^{10}$ Psychologist Evelin Linder offers extended discussions of the damaging effects of humiliation in conflict around the world and suggests steps needed to create non-humiliating global communities (e.g. Linder, 2001, 2006). She also describes her own remarkable personal career as a nomadic investigator and community builder.
} 
The rising tide of populism in the US, and elsewhere in the world, has destabilized political establishments and led to the realignment of political allegiances. While political upheavals can be constructive, those manifest in the current rise of populism have undermined the very institutions that contributed to the growing prosperity and unprecedented security so many working class Americans enjoyed in decades following the end of the Second World War. ${ }^{\text {lvii }}$

Populism's challenge to liberal democracy, especially in the context of the dislocation and displacement of globalization, pointedly raises the question of who "counts" in the relevant shared future-who is included in, and who is excluded from, the demos? Given the scourges of racism and white supremacy that sully our history, it is a question with profound moral and political implications. ${ }^{\text {Iiii }}$

In a blistering indictment of Donald Trump and Trump voters published The Atlantic, Ta-Nehisi Coates marshals the damning facts of ongoing racism and castigates main-line journalists for focusing so much attention on the plight of white working class Americans and ignoring, or at least downplaying, evidence of the renewed racism that has been unleashed in the current US political environment. ${ }^{\text {lix }}$ He claims that reference to the white working class as a real and distinct community has become a rhetorical device for silencing those who insist on including issues of inclusiveness and diversity in discussions of Americans' shared future.

\section{The Pros and Cons of Compromise}

There is an obvious need for a viable political agenda that could unite rather than divide those in danger of being left behind and those seeking to catch up. While we have not tried to suggest the appropriate tradeoffs in such an agenda, we have identified and highlighted some core themes that underpin the "shoulder-to-shoulder" politics of a shared future - fostering dignity, safeguarding livelihoods, and encouraging respect. A central question that will have to be addressed is when, and over what, the parties pursuing the vision of a bearable shared future might need to compromise.

In On Compromise and Rotten Compromises, Avishai Margalit explicitly discusses the role of compromise in balancing desires for peace and desires for justice. In that discussion, he makes a distinction between the types of painful compromises that must sometimes be endured to secure the blessings of peace and the opportunities it affords, and rotten compromises, which he sees as morally impermissible and must be avoided "come what may"- that is, regardless of circumstances and costs to be borne. ${ }^{1 \mathrm{x}}$ All other compromises, he argues, must be evaluated on their own merits on a "retail" or case-by case basis.

The issue is not whether bad compromises - that is, shady compromises ("deals that serve suspicious motives"), shoddy compromises (acceptance of "phony goods" in exchange for things of real value), or shabby compromises (exploitative exchanges that take "advantage of the vulnerability of the weaker party") — should be accepted when better deals could be made. ${ }^{\text {lxi }} \quad$ Margalit writes: "These are all forms of morally bad deals, yet given the alternatives, they might on occasion be justified" (p. 4). Whether a compromise is to be accepted or rejected, even an unjust one, depends upon the specific burdens it imposes and/or perpetuates, the longer-term outcomes likely to result from it, and how the balance of burdens and benefits will be allocated and shared by the weak and/or disadvantaged versus the strong and/or advantaged.

Margalit offers the provocative claim that we should be "judged by our compromises more than by our ideals" (p. 5). Our ideals indicate what we would most like, but our compromises reveal our ultimate priorities and what prices we will pay to achieve those priorities. The dynamics of power cannot be overlooked in such assessments of morality. Compromises that are coerced or imposed are suspect. Free consent of the weaker party is the defining factor. It is the weaker party that must decide whether to accept terms that unjust or morally suspect. The stronger party should simply refrain from offering morally bad terms.

\section{Summing up}

We have described the "four-question" framework that we and our SCICN colleagues developed in the course of work encouraging constructive dialogue and difficult compromises on the part of parties engaged in seeming intractable conflicts in various parts of the world. We have further suggested that the same framework could provide a useful lens for examining the political divides that we see in the US and many other democratic countries facing the challenges of globalization. We have acknowledged the economic threats and losses that globalization has imposed, but beyond those losses we have focused on the role that the loss of dignity, recognition, and community standing, is playing in creating divisions, fueling resentment, and stoking the fires of populism and intolerance. We have had little to say about the design of potentially ameliorate economic policies. We have merely acknowledged the obvious need to provide a decent standard of living and greater security for the most vulnerable, and the need to deliver those benefits in a non-humiliating manner. Our main suggestions have pertained to strategies to address problems of distrust, the particular susceptibility to hate-mongering populist leaders shown by those who are feeling the most painful losses, and the thorny question of just entitlements. While we have cited the need for compromise and willingness to engage in 
difficult exchanges of views, we have also tried to distinguish necessary but painful compromises from ones we deem unacceptable. We hope our efforts will encourage others to take up the challenges and opportunities required to create, and realize, a shared future that is not only bearable but satisfying and even ennobling.

\section{References}

Arendt, H. (1963). On revolution. New York, NY, USA: Penguin Books.

Arendt, H. (1958). The human condition. Chicago, IL, USA: The University of Chicago Press.

Arendt, H. (1954). What is freedom. In H. Arendt, Between past and future (pp. 142-169). New York, NY, USA: Penguin Books.

Ariely, D. (2012, August 2). Americans want to live in a much more equal country (they Just don't realize it). Retrieved from

The Atlantic:

https://www.theatlantic.com/business/archive/2012/08/americans-want-to-live-in-a-much-more-equal-country-they -just-dont-realize-it/260639/

Arrow, K., Mnookin, R. H., Ross, L., Tversky, A., \& Wilson, R. (1995). Barriers to conflict resolution. New York, NY, USA: W. W. Norton \& Company.

Bellah, R. N., Madsen, R., Sullivan, W. M., Swidler, A., \& Tipton, S. M. (1985). Habits of the heart: individualism and commitment in American life. Berkeley, CA, USA: University of California Press.

Bland, B., \& Powell, B. M. (2014, Spetember). Track two in a hostile peace: Northern ireland. Retrieved from Stanford Center on International Conflict and Negotiation Working Papers: https://law.stanford.edu/index.php?webauth-document=child-page/370999/doc/slspublic/WP\%20Doc\%20211.pdf

Bland, B., Powell, B., \& Ross, L. (2012). Barriers to dispute resolution: reflections on peacemaking and relationships between adversaries. In R. Goodman, D. Jinks, \& A. K. Wood, Understanding social action, promoting human rights(pp. 265-291). Oxford, England, UK: Oxford University Press.

Brownstein, R. (2018, June 12). Republicans and Democrats increasingly really do occupy different worlds. Retrieved from CNN.com: https://www.cnn.com/2018/06/12/politics/republicans-democrats-different-worlds/index.html

Buruma, I. (2006). Murder in Amsterdm: the death of Theo van Gogh and the limits of tolerance. London, England, UK: The Peguin Press.

Caldwell, C. (2017, April). American carnage: the new landscape of opioid addittion. Retrieved from First things: https://www.firstthings.com/article/2017/04/american-carnage

Caldwell, C. (2017, April 17). The French, coming apart. Retrieved from City Journal Magazine: https://www.city-journal.org/html/french-coming-apart-15125.html

Chua, A. (2018). Political tribes: group instincts and the fate of nations. New York, NY: Penguin Publishing Group.

Coates, T.-N. (2017, September 7). The First White President. Retrieved from The Atlantic: https://www.theatlantic.com/magazine/archive/2017/10/the-first-white-president-ta-nehisi-coates/537909/

Cohen, R. (2016, may 30). Americans, Let's Talk. Retrieved from New York Times: https://www.nytimes.com/2017/05/30/opinion/donald-trump-colorado-roger-cohen.html?_r=0

Collins, M. (2015, May 6). The pros and cons of globalization. Retrieved from Forbes : https://www.forbes.com/sites/mikecollins/2015/05/06/the-pros-and-cons-of-globalization/\#7a33d6beccce

Cooper, J. M. (1999). Reason and emotion. Princeton, NJ, USA: Princeton University Press.

Cowen, T. (2016, April 8). Economic development in an "Average is Over" world. Retrieved from https://www.gmu.edu/centers/publicchoice/faculty\%20pages/Tyler/Manila.pdf

Cowen, T. (2017, February 16). Industrial revolution comparisons aren't comforting. Retrieved from Bloomberg View: https://www.bloomberg.com/view/articles/2017-02-16/industrial-revolution-comparisons-aren-t-comforting

Dalio, R. (2017, October 23). Our biggest economic, social, and political issue the two economies: the top 40\% and the bottom $60 \%$. Retrieved from in https://www.linkedin.com/pulse/our-biggest-economic-social-political-issue-two-economies-ray-dalio/

Eberstadt, N. N. (2017, February 15). Our miserable 21st century. Retrieved from Commentary Magazine: https://www.commentarymagazine.com/articles/our-miserable-21st-century/ 
https://www.commentarymagazine.com/articles/our-miserable-21st-century/

Edsall, T. B. (2017, July 20). How Fear of falling explains the love of trump. Retrieved from New York Times: https://www.nytimes.com/2017/07/20/opinion/how-fear-of-falling-explains-the-love-of-trump.html?_r=0

Edsall, T. B. (2017, October 12). The Democrats are playing checkers while Trump is placing chess. Retrieved from New York Times: https://nyti.ms/2kJkIYL

Edsall, T. B. (2018, April 19). The Democrats' Gentrification Problem. Retrieved from New York Times: https://nyti.ms/2vxwniO

Edsall, T. B. (2017, March 16). The increasing significance of the decline of men. Retrieved from New York Times: https://nyti.ms/2nuIEw8

Fisher, R., \& Ury, W. (1981). Getting to yes. New York, NY, USA: Penguin Books.

Freire, P. (1970). Pedagogy of the oppressed. New York, NY, USA: Herder \& Herder.

Friedman, T. L. (2016). Thank ou for being late: an optimist's guide to thriving in the age of accelerations . New York City, NY, USA: Farrar, Straus and Giroux.

Fukuyama, F. (forthcoming). Identiy: the demand for dignity and the politics of resentment. Farrar, Straus and Giroux.

Gage, B. (2017, August 15). an intellectual historian argues his case against identity politics. Retrieved from New York Times: https://www.nytimes.com/2017/08/15/books/review/mark-lilla-the-once-and-future-liberal.html

Gilovich, T., \& Ross, L. (2015). The objectivity illusion. In T. Gilovich, \& L. Ross, The wisest one in the room: how you can benefit from social psychology's most powerful insights. New York, NY, USA: Free Press.

Girard, R. (1989). The Scapegoat. Baltimore, MD, USA: Johns Hopkins University Press.

Glaeser, E., Austin, B., \& Summers, L. (2018, March 7). Saving the heartland: place-based policies in 21st century America. Retrieved from Brooking Institute: https://www.brookings.edu/bpea-articles/saving-the-heartland-place-based-policies-in-21st-century-america/

Hacker, J. S., \& Pierson, P. (2016). American amnesia: how the war on government led us to forget what made America prosper. New York, NY, USA: Simon \& Schuster.

Haidt, J. (2016, July 10). When and why nationalism beats globalism. Retrieved from The American Interest: https:/www.the-american-interest.com/2016/07/10/when-and-why-nationalism-beats-globalism/

Hardin, R. (2002). Trust and trustworthiness. New York, NY, USA: Russel Sage Foundation.

Hobbes, T. (1958). Leviathan. Indianapolis, IN, USA: The Bobbs-Merrill Company, INC.

Hochschild, A. (2016). Strangers in the own land: anger and morning on the American right. New York, NY, USA: The New Press.

Hu, F., \& Spence, M. (2017, July/August). Why globalism stalled: and how to restart it. Foreign Affairs .

Irwin, N. (2018, March 23). Globalization's backlash is here, just at the wrong time. Retrieved from New York Times: https://nyti.ms/2pzgLFN

Irwin, T. (2017, September 4). To understand rising inequality, consider the janitors at two top companies, now and then. Retrieved from New York Times: https://nyti.ms/2x1YnuD

Judis, J. B. (2016). The populisty explosion: how the great recession transformed American and European politics. New York, NY, USA: Columbia Global Reports.

Kahneman, D. (2011). Thinking, fast and slow. New York, NY, USA: Farrar, Staus and Giroux.

Kahneman, D., \& Tversky, A. (2000). Prospect theory: an analysis of decision under risk. In D. Kahneman, \& A. Tversky, Choices, values, and frames (pp. 17-43). Cambridge, UK: Cambridge University Press.

King, Jr., M. L. (1958). Strides toward freedom. Boston, MA, USA: Beacon Press.

Kriesi, H., Grande, E., Lachat, R., Dolezal, M., Bornschier, S., \& Frey, T. (2006). Globalization and the transformation of the national Political space: six European countries compared. European Journal of Political Research , 45 (6), 921-56.

Lennon, B. (2004). Peace comes dropping slowly: dialogue and conflict management in Northern ireland . Belfast, Northern Ireland, UK: Community Dialogue.

Lerner, M. (2002). Pursuing the justice motive. In M. Lerner, M. Ross, \& D. T. Miller, The justice motive in 
everyday ; ife. Cambridge, England, UK: Cambridge University Press.

Levinas, E. (1982). Ethics and infinity. Pittsburg, PA, USA: Duquesne University Press.

Lewicki, R. J., \& Wiethoff, C. (2000). Trust, trust development, and trust repair. In M. Deutsch, \& P. T. Coleman, The handbook of conflict resolution: theory and practice (pp. 86-107). San Franscico, CA, USA: Jossey=Bass Publishers.

Lilla, M. (2017). The once and future liberal: after identity politics. New York, NY, USA: HarperCollins Publishers.

Lind, M. (2014, April 24). The coming realignment: cities, class, and ideology after social conservatism. Retrieved from Breakhrough: https://thebreakthrough.org/index.php/journal/past-issues/issue-4/the-coming-realignment

Lind, M. (2017, May 20). The new class war. Retrieved from American Affairs: https://americanaffairsjournal.org/2017/05/new-class-war/

Lindner, E. G. (2006). Making Enemies: Humiliation and International Conflict,. Westport, CN, USA: Praeger.

Lindner, E. G. (2001). The Psychology of Humiliation. Somalia, Rwanda / Burundi, and Hitler's Germany. Oslo, Norway: The Psychology of Humiliation. Somalia, Rwanda / Burundi, and Hitler's Germany.

Margalit, A. (2017). On betrayal. Cambridge, MA, USA: Harvard University Press.

Margalit, A. (2010). On compromise and rotten compromises. Princeton, NJ, USA: Princeton University Press.

Margalit, A. (1996). The decent society. Cambridge, MA, USA: Harvard University Press.

Margalit, A. (2002). The ethics of memory. Cambridge, MA, USA: Harvard University Press.

Metacalf, S. (2017, August 18). Neoliberalism: the idea that swallowed the world. Retrieved from The Guardian: https://www.theguardian.com/news/2017/aug/18/neoliberalism-the-idea-that-changed-the-world?

Miller, P. D. (2017, February 10). Globalism is the victory of western Ideas. Retrieved from Foreign Policy: http://foreignpolicy.com/2017/02/10/globalism-is-the-victory-of-western-ideals/

Mnookin, R., \& Ross, L. (1995). Introduction. In K. Arrow, R. H. Mnookin, L. Ross, A. Tversky, \& R. Wilson, Barriers to conflict resolution (pp. 3-24). New York, NY, USA: W. W. Norton \& Company.

Muller, J.-W. (2016). What is Populism? Philadelpha, PA, USA: University of Pennsylvania Press.

Mutz, D. C. (2018, April 23). Status threat, not economic hardship, explains the 2016 presidential vote. Retrieved from Proceedings of the National Academy of Sciences of the United States of America: http://www.pnas.org/content/early/2018/04/18/1718155115

Paulozzi, L., Mack, K., \& Hockenberry, J. (2014, July 4). Vital signs: variation among states in prescribing opioid pain relievers and benzodiazepines -- United States 2012. Retrieved from Center for disease control and prevention: https://www.cdc.gov/mmwr/preview/mmwrhtml/mm6326a2.htm?s_cid=mm6326a2_w

Pilkington, E. (2017, July 9). What happend when Walmart left. Retrieved from The Guardian : https://www.theguardian.com/us-news/2017/jul/09/what-happened-when-walmart-left

Porter, E. (2016, December 13). Where were the Trump votes? Where the jobs weren't. Retrieved from New York Times: https://www.nytimes.com/2016/12/13/business/economy/jobs-economy-voters.html?_r=0

Rawls, J. (1971). A theory of justice. Cambridge, MA, USA: Harvard University Press.

Renwick, C. (2017, September 21). Why we need the welfare state more trhan ever. Retrieved from The Guardian: https://www.theguardian.com/news/2017/sep/21/why-we-need-the-welfare-state-more-than-ever?utm_source=esp \&utm_medium=Email\&utm_campaign=The+Long+Read+-+Collections $+2017 \& u t m \_t e r m=244858 \&$ subid=21193 $741 \&$ CMP=longread_collection

Rogers, J. R. (2017, December 20). Understanding the conservative split over globalization. Retrieved from Law and Liberty: http://www.libertylawsite.org/2017/12/20/understanding-the-conservative-split-over-globalization/

Rosenboim, O. (2017, July 10). Globalism and Nationalism. Retrieved from Foreign Affairs: https://www.foreignaffairs.com/articles/2017-07-10/globalism-and-nationalism

Ross, L., \& Nisbett, R. E. (1991). The person and the situation: perspectives of social psychology. New York, NY, USA: McGraw-Hill, Inc.

Ross, L., \& Ward, A. (1994). Psychological barriers to dispute resolution. In M. Zanna, Advances in experimental social psychology. San Diego, CA, USA: Academic Press.

Rothwell, J. (2017, September 16). The Minuscule Importance of Manufacturing in Far-Right Politics. Retrieved from 
New York Times: https://nyti.ms/2y2PUEb

Santens, S. (2017, October 24). The real story of automatiob beginning with one simple chart. Retrieved from Medium: https://medium.com/basic-income/the-real-story-of-automation-beginning-with-one-simple-chart-8b95f9bad71b

Seligman, A. (1977). The problem of trust. Princeton, NJ, USA: Princeton University Press.

Sherif, M., Harvey, O. J., White, B. J., Hood, W. R., \& Sherif, C. W. (1954). Intergroup conflict and cooperation: the Robbers Cave experiment. Retrieved from Classics in the History of Psychology: https://www.free-ebooks.net/ebook/Intergroup-Conflict-and-Cooperation-The-Robbers-Cave-Experiment/pdf?dl\& preview

Starmans, C., Sheskin, M., \& Bloom, P. (2017, Month 7). Why people prefer unequal societies. Retrieved from Nature: human behavior: https://www.nature.com/articles/s41562-017-0082

Stelzenmuller, C. (2017, September 25). Normal is over. Retrieved from Brookings: https://www.brookings.edu/wp-content/uploads/2018/02/fp_20180201_normal_is_over1.pdf

Stewart, M. (2018, May 16). The 9.9 percent Is the new American aristocracy. Retrieved from The Atlantic: https://www.theatlantic.com/magazine/archive/2018/06/the-birth-of-a-new-american-aristocracy/559130/

Vance, J. D. (2016). Hillbilly Elergy: a memior of a family and culture in crisis. New York, NY, USA: HarperCollins.

Weber, M. (2002). The Protestant work ethic and the spirit of capitalism. New York, NY, USA: Penguin Books.

Weintraub, J. (1997). The theory and politics of the public/private distinction. In J. Weintraub, \& K. Kumar, public and private in thought and practice: perpectives on a grand dichotomy (pp. 1-42). Chicago, IL, USA: The University of Chicago Press.

Williams, T. C. (2017, October 6). How Ta-Neshisi Coates give whiteness power. Retrieved from New York Times: https://nyti.ms/2yLJUzL

Wuthnow, R. (2018). The left behind: decline and rage in rural America. Princeton, NJ, USA: Princeton University Press.

\section{Copyrights}

Copyright for this article is retained by the author(s), with first publication rights granted to the journal.

This is an open-access article distributed under the terms and conditions of the Creative Commons Attribution License which permits unrestricted use, distribution, and reproduction in any medium, provided the original work is properly cited.

\footnotetext{
${ }^{\text {i }}$ Brownstein, 2018

ii Kahneman \& Tversky, Prospect theory: an analysis of decision under risk, 2000; Kahneman, Thinking, fast and slow, 2011; Arrow, Mnookin, Ross, Tversky, \& Wilson, 1995

iii Dalio, 2017; Edsall, The Democrats' Gentrification Problem, 2018

iv Eberstadt, Our miserable $21^{\text {st }}$ century, 2017

v Caldwell, American carnage: the new landscape of opioid addittion, 2017)

vi Paulozzi, Mack, \& Hockenberry, 2014

vii Edsall, T. B., The increasing significance of the decline of men, 2017

viii Rosenboim, 2017

ix Miller, 2017; Renwick, 2017; Lind, The new class war, 2017; Hu \& Spence, 2017

${ }^{x}$ Rogers, 2017

xi Collins, 2015

xii $\mathrm{Hu} \&$ Spence, 2017

xiii For an insightful account of the impact of globalization on France, see Caldwell, The French, coming apart, 2017.

xiv Hochschild, 2016

${ }^{x v}$ Hochschild, 2016, Kindle location 2311-2357

xvi Weintraub, 1997

xvii Bland \& Powell, 2014.

xviii http://www.pbs.org/newshour/bb/europe-july-dec12-nireland_07-11/

xix Sherif, Harvey, White, Hood, \& Sherif, 1954; Ross \& Nisbett, 1991, pp. 38-41
} 
xx Arrow, Mnookin, Ross, Tversky, \& Wilson, 1995

${ }^{x x i}$ Lennon, 2004

xxii Lennon, 2004, p125

xxiii Fisher \& Ury, 1981

xxiv Margalit, On betrayal, 2017

${ }^{x x v}$ Fukuyama, forthcoming

xxvi See Coates, 2017; Gage, 2017

xxvii Girard, 1989

xxviii Cowen, 2017

xxix Cowen, 2016

xxx Irwin, N. 2018

xxxi Lee, 2017

xxxii Glaeser, Austin, \& Summers, 2018)

xxxiii Lind, 2017

xxxiv Lewicki \& Wiethoff, 2000

xxxv Seligman, 1977, p172

xxxvi Edsall, T. B., How Fear of falling explains the love of trump, 2017; Mutz, 2018; Stelzenmuller, 2017

xxxvii Irwin, T., 2017

xxxviii Chua, A, 2018, p 173

xxxix Cooper, 1999, p 368 \& p 374

xl Arendt, 1958, 243

xli Margalit, 1996, pp 70-75

xlii Margalit, 1996, pp247-261

xliii Pilkington, 2017

xliv Irwin N., 2018

xlv Santens, 2017

xlvi Margalit, 1996, p214

xlvii Hochschild, 2016, Kindle Locations 2526-2527

xlviii Stewart, 2018

xlix Margalit, 1996, pp281-284

${ }^{1}$ Rawls, 1971

li Gilovich \& Ross, 2015

lii Starmans, Sheskin, \& Bloom, 2017

liii Ariely, 2012

liv Vance, 2016, p189

lv Muller, 2016

lvi Muller, 2016, Kindle Location 170-171

lvii Judis, 2016, Kindle Location 120-121

lviii See Rothwell, 2017 and Edsall, The Democrats are playing checkers while Trump is placing chess, 2017

lix Coates, 2017

lx Margalit, 2010, pp 117-119

lxi Margalit, 2010, pp 3-4 